\title{
Beta-2 Globulin Measurement
}

National Cancer Institute

\section{Source}

National Cancer Institute. Beta-2 Globulin Measurement. NCI Thesaurus. Code C119276.

The determination of the amount of the beta-2 globulin activity in a biological specimen. 